\title{
Pembinaan Keterampilan Produktif Sebagai Upaya Pemberdayaan Masyarakat Desa Membangun
}

\author{
Abd. Hamid Isa', Zulkarnain Anu² \\ ${ }^{1,2}$ Fakultas IImu Pendidikan Universitas Negeri Gorontalo Jl. Jend. Sudirman No.6, \\ Dulalowo Timur, Kota Tengah, Kota Gorontalo, Gorontalo 96128, Indonesia \\ Email: abdhamid_ung@yahoo.co.id ${ }^{1}$, infozulkarnain@ung.ac.id ${ }^{2}$
}

\begin{abstract}
The development village paradigm allows villagers to determine their own development priorities and visions because the decisions are made in village deliberations. Another advantage of the village development movement is that rural communities are encouraged to be independent in formulating their steps to build village welfare. Residents also become much more enthusiastic about carrying out the development of their village because they have the right and authority to determine what their village needs. The Thematic Community Service Program by LPPM UNG in 2021 is oriented to improve the quality of the number of UNG lecturers who have been implemented and are able to be efficient for the community according to the mission of the Ministry of Villages PDTT (1) Accelerating sustainable rural and rural development; (2) Develop the economy and investment in Villages and Rural Areas, Disadvantaged Regions, and Transmigration areas. The development of productive skills for rural communities in coastal areas is one of the strategic programs to support the implementation of Thematic Community Service Program. This is important because the coastal area is a priority program for universities to intervene both in terms of educational policies and efforts to accelerate economic resilience which has an impact on increasing income and welfare of the community. The target of developing productive skills for coastal communities through the Thematic Community Service Program is to participate with village communities to provide support for productive skills, especially for people in need as an educational effort on the one hand, and as an alternative solution to developing skills that have economic value to meet the needs of increasing income. and the quality of life of rural communities on the other hand. The achievements of this activity are the implementation of the development of productive skills of the target community, among others, (1) Development and training of tourism awareness groups, (2) BUMDES management, (3) the use of organic waste, (4) training on processed fish products of Sunglir (sulo-sulo), (5) katinting machine maintenance skills, and (6) IT public relations training for youth organizations. The level of community participation in this activity is relatively good, it is recommended that such a program be continued as an effort to empower the community to be able to manage their potential independently which in turn can create high efficiency for village development.
\end{abstract}

Keywords: Village Building; productive skills; community empowerment.

\begin{abstract}
Abstrak
Paradigma desa membangun memungkinkan warga desa menentukan sendiri prioritas dan visi pembangunannya sendiri karena keputusannya dilakukan dalam musyawarah desa. Keunggulan lain dari gerakan desa membangun, masyarakat desa terdorong menjadi mandiri dalam merumuskan langkahnya membangun kesejahteraan desa. Warga juga menjadi jauh lebih bersemangat menjalankan pembangunan desanya karena mereka memiliki hak dan wewenang menentukan apa yang desa mereka butuhkan. Program KKN Tematik oleh LPPM UNG Tahun 2021 diorientasikan untuk meningkatkan kualitas jumlah pengabdian dosen UNG yang telah diimplementasikan dan mampu berdaya guna bagi masyarakat sesuai misi Kemendesa PDTT (1) Mempercepat pembangunan Desa dan Perdesaan yang berkelanjutan; (2) Mengembangkan ekonomi dan investasi di Desa dan Perdesaan, Daerah Tertinggal, dan kawasan Transmigrasi. Pembinaan keterampilan produktif bagi masyarakat desa kawasan pesisir merupakan salah satu program strategis untuk mendukung penyelenggaraan KKN Tematik. Hal ini
\end{abstract}


penting dilakukan karena kawasan pesisir menjadi program prioritas bagi Perguruan Tinggi untuk diintervensi baik dari segi kebijakan pendidikan maupun upaya percepatan ketahanan ekonomi yang berdampak pada peningkatan pendapatan dan kesejahteraan masyarakatnya. Target pembinaan keterampilan produktif bagi masyarakat pesisir melalui program KKN Tematik ini adalah berperan serta bersama masyarakat desa untuk memberikan dukungan terhadap keterampilan produktif khususnya bagi masyarakat yang membutuhkan sebagai upaya pendidikan disatu pihak, dan sebagai solusi alternatif terhadap pengembangan keterampilan yang bernilai ekonomi untuk memenuhi kebutuhan peningkatan pendapatan dan kualitas hidup masyarakat desa dipihak lain. Capaian kegiatan ini terlaksananya pembinaan keterampilan produktif masyarakat sasaran antara lain, (1) Bina dan pelatihan kelompok sadar wisata, (2) pengelolaan BUMDES, (3) pemanfaatan sampah organik, (4) pelatihan produk olahan ikan sunglir (sulo-sulo), (5) keterampilan perawatan mesin katinting, dan (6) pelatihan humas IT bagi organisasi kepemudaan. Tingkat partisipasi masyarakat dalam kegiatan ini relatif baik, direkomendasikan agar program demikian dilanjutkan sebagai upaya memberdayakan masyarakat agar mampu mengelola potensinya secara mandiri yang pada gilirannya bisa menciptakan efisiensi tinggi bagi pembangunan desanya.

Kata Kunci : Desa membangun; keterampilan produktif; pemberdayaan masyarakat.

(C) 2021 Abd. Hamid Isa, Zulkarnain Anu Under the license CC BY-SA 4.0 Correspondence author: Zulkarnain Anu, infozulkarnain@ung.ac.id, Gorontalo, and Indonesia

\section{PENDAHULUAN}

Salah satu kebijakan pembangunan yang sangat strategis adalah memposisikan desa sebagai basis dan tujuan pembangunan terutama sejak disahkannya Undang-Undang Nomor 6 Tahun 2014 tentang Desa. Undang-undang ini menempatkan desa sebagai subyek pelaku pembangunan. Kini desa dan masyarakat desa melalui struktur yang ada memiliki wewenang penuh menjalankan pembangunan desanya. Modalnya selain aset dan potensi yang ada di desa juga ditambah dana desa yang jumlahnya juga sangat mendukung gerakan pembangunan desa. Paradigrma ini disebut sebagai 'desa membangun'.

Gerakan desa membangun mewadahi para pegiat desa untuk menciptakan ruang belajar kolektif dalam tata kelola sumber daya desa. Inisiatif dan kemampuan desa dalam mengelola sumber daya yang ada di wilayahnya menjadi modal dasar untuk mewujudkan desa yang kuat, maju, dan mandiri. Teknologi informasi merupakan sarana belajar yang mampu menjembatani para pegiat desa di berbagai daerah di Indonesia.

Ada beberapa strategi yang secara umum dipraktikkan dalam membangun kemandirian desa. Pertama, membangun kapasitas warga dan organisasi masyarakat sipil di desa yang kritis dan dinamis. Kedua, 
memperkuat kapasitas pemerintahan dan interaksi dinamis antara organisasi warga dalam penyelenggaraan pemerintahan desa Ketiga, membangun sistem perencanaan dan penganggaran desa yang responsif dan partisipatif. Keempat, membangun kelembagaan ekonomi lokal yang mandiri dan produktif (Kurniawan, 2015).

Seiring dengan kebijakan mencapai tujuan pembangunan berkelanjutan dari desa Sustainable Development Goals (SDGs) maka gerakan desa membangun merupakan suatu keniscayaan yang patut untuk dikembangkan dan bahkan diperjuangkan. Hal ini berasalan karena Sustainable Development Goals (SDGs) merupakan suatu rencana aksi global yang disepakati oleh para pemimpin dunia, termasuk Indonesia guna mengakhiri kemiskinan, mengurangi kesenjangan dan melindungi lingkungan. Sebagai bagian dari upaya untuk mencapai target tujuan pembangunan berkelanjutan nasional (SDGs Nasional) hingga ke tingkat desa, Kementerian Desa Pembangunan Daerah Tertinggal dan Transmigrasi (Kemendes PDTT) menerbitkan Permendesa PDTT No. 13 Tahun 2020 yang berfokus pada SDGs desa. Dalam regulasi ini diatur tentang prioritas penggunaan dana desa pada tahun 2021 yang juga fokus terhadap upaya pencapaian SDGs. Permendesa PDTT Nomor 13 tahun 2020 ini dilatarbelakangi pemikiran terkait dengan model pembangunan nasional yang didasarkan pada Peraturan Presiden Nomor 59 tahun 2017 terkait dengan pelaksanaan pencapaian tujuan pembangunan nasional berkelanjutan (Ghufran \& K., 2020).

Berkenaan dengan pembangunan terfokus berdasarkan SDGs Desa maka kebijakan Kementerian Desa, Pembangunan Daerah Tertinggal dan Transmigrasi (Kemendes PDTT) telah membagi sembilan tipe desa yang sesuai dengan SDGs desa, yaitu desa tanpa kemiskinan dan kelaparan, desa ekonomi tumbuh merata, desa peduli kesehatan. Kemudian desa peduli lingkungan hidup, desa peduli pendidikan, desa ramah perempuan, desa berjejaring, desa tanggap budaya, dan desa Pancasila.

Program Kuliah Kerja Nyata (KKN) Tematik yang dilaksanakan oleh LPPM UNG pada periode ini membawa tema "Kampus Merdeka untuk 
Desa : KKNT Desa Membangun demi Pencapaian SDGs (Suistainable Development Goals)". Penentuan tema ini juga didasarkan target sasaran RENSTRA Kemendesa PDTT 2020 - 2024 yaitu "Terwujudnya Perdesaan yang memiliki keunggulan Kolaboratif dan Daya Saing secara berkelanjutan dalam Mendukung Indonesia Maju yang Berdaulat, Mandiri, dan Berkepribadian, Berlandaskan Gotong-Royong" (LP2M \& UNG, 2021).

Program KKN Tematik oleh LPPM UNG Tahun 2020 diorientasikan untuk meningkatkan kualitas jumlah pengabdian dosen UNG yang telah diimplementasikan dan mampu berdaya guna bagi masyarakat sesuai misi Kemendesa PDTT (1) Mempercepat pembangunan Desa dan Perdesaan yang berkelanjutan; (2) Mengembangkan ekonomi dan investasi di Desa dan Perdesaan, Daerah Tertinggal, dan kawasan Transmigrasi (LP2M \& UNG, 2021).

Selanjutnya paradigma pembangunan desa membangun saat ini lebih memberikan ruang yang memadai bagi masyarakat agar berdaya dan berpartisipasi dalam proses pembangunan. Menurut Sumardjo dan Saharudin dalam jurnal (Tampubolon, 2003) bahwa partisipasi masyarakat diperlukan karena partisipasi berarti : (1) mensukseskan program secara lebih terjamin dan lebih cepat; (2) mendekatkan pengertian pihak perencana/ pengelola dengan kebutuhan golongan sasaran; (3) media untuk memupuk keterampilan masyarakat, kekeluargaan, dan kepercayaan diri; dan (4) mencapai partisipasi positif sebagai ciri khas masyarakat modern.

Menurut Teguh dalam Jurnal (Tampubolon, 2003) bahwa dalam konteks pembangunan nasional upaya pemberdayaan masyarakat dapat dilihat dari beberapa sudut pandang. Pertama, penciptaan suasana atau iklim yang memungkinkan masyarakat berkembang. Kedua, peningkatan kemampuan masyarakat dalam membangun melalui berbagai bantuan dana, pelatihan, pembangunan prasarana dan sarana baik fisik maupun sosial,serta pengembangan kelembagaan di daerah. Ketiga, perlindungan struktur sosial masyarakat dalam sistem sosial menjadi faktor terpenting 
dalam melaksanakan pemberdayaan masyarakat, termasuk di dalamnya sistem ekonomi dan politik.

Sebagai upaya untuk mendukung penyelenggaraan KKN Tematik dan implementasi terwujudnya pedesaan yang memiliki keunggulan kolaboratif dan berdaya saing berkelanjutan maka salah satu program yang strategis dikembangkan adalah dengan melaksanakan program pembinaan keterampilan produktif bagi masyarakat desa kawasan pesisir. Hal ini penting dilakukan karena kawasan pesisir menjadi program prioritas bagi Perguruan Tinggi untuk diintervensi baik dari segi kebijakan pendidikan maupun upaya percepatan ketahanan ekonomi yang berdampak pada peningkatan pendapatan dan kesejahteraan masyarakatnya.

Keterampilan produktif yang dalam konteks teori disebut juga pendidikan kecakapan hidup. Pentingnya pendidikan kecakapan hidup bagi setiap pribadi karena masyarakat menghadapi berbagai masalah yang harus senantiasa diselesaikan dalam kehidupannya sehari-hari. Kecakapan hidup itulah yang diperlukan pada individu memasuki kehidupan yang mandiri, anggota masyarakat dan warga negara. Sehingga dengan penguasaan terhadap life skills, individu diharapkan akan menjadi individu yang mampu memecahkan permasalahanpermasalahannya dengan menemukan alternatif atau solusi yang tepat yang berimplikasi positif bagi dirinya sendiri maupun bagi orang-orang yang berada di sekitar kehidupannya. Perilaku dan karakter inilah yang akan menyebabkan mereka bisa beradaptasi dengan perkembangan dan kemajuan zaman, survive dan bisa memberikan kontribusi yang berarti bagi bangsanya.

Pembinaan keterampilan produktif sebagai salah implementasi pendidikan kecakapan hidup perlu dikembangkan karena dengan bekal keterampilan yang dimiliki mampu meningkatkan kualitas hidup masyarakat sejalan dengan perkembangan zaman. Dalam hal ini Sondra Stein (dalam (Isa et al., 2017)) menjelaskan bahwa terdapat empat kategori standar yang perlu dipersiapkan pada masa depan untuk 
kecakapan orang dewasa, yaitu: pertama mendapatkan informasi dan ideide, kedua mengkomunikasikan dengan penuh percaya diri pesannya dan dapat dimengerti oleh orang lain, ketiga membuat keputusan yang didasarkan pada informasi yang valid dan mampu menganalisis serta dapat memutuskan secara cermat, ke empat selalu belajar agar tidak tertinggal oleh kemajuan ilmu pengetahuan.

Target kegiatan pembinaan keterampilan produktif bagi masyarakat desa di kawasan pesisir yang dilakukan melalui program KKN Tematik ini adalah berperan serta bersama masyarakat desa untuk memberikan dukungan terhadap keterampilan produktif khususnya bagi masyarakat yang membutuhkan sebagai upaya pendidikan disatu pihak, dan sebagai solusi alternatif terhadap pengembangan keterampilan yang bernilai ekonomi yang sangat diperlukan untuk memenuhi kebutuhan peningkatan pendapatan dan kualitas hidup masyarakat desa dipihak lain.

\section{METODE PELAKSANAAN}

Pendekatan yang dilakukan dalam mengimplementasikan kegiatan pembinaan keterampilan produktif yang terintegrasi dengan program KKN Tematik mengacu disain kegiatan yang diprogramkan oleh LP2M Universitas Negeri Gorontalo. Program aksi KKN Tematik Desa Membangun dengan pilihan program pembinaan keterampilan produktif bagi masyarakat desa Botuboluo Kecamatan Biluhu Gorontalo, dibagi atas 4 (empat) tahap.

Tahap 1 Pendampingan Perencanaan Pembangunan Desa, meliputi: (a) Pelaksanaan survey dan observasi lapangan. (b) Asesmen kebutuhan masyarakat, (c) Rapat pembahasan (Hasil observasi dan Asesmen Kebutuhan).

Tahap 2 Pendampingan Pelaksanaan, Evaluasi Pembangunan Desa, meliputi: (a) Membahas program KKN Tematik Asesmen Kebutuhan Masyarakat, (b) Menyusun program KKN Tematik Asesmen Kebutuhan Masyarakat, (c) Membahas sumber-sumber dana pembiayaan kegiatan, (d) Penyampaian dan Analisis hasil asesmen kepada Pemerintah Desa untuk rekomendasi, dan (e) Penetapan program prioritas KKN Tematik. 
Tahap 3 Inisiasi Meningkatkan Kehidupan Masyarakat Desa, meliputi: (a) Pelaksanaan Program Kerja (Pelatihan Keterampilan Produktif Masyarakat Desa), (b) Pelaksanaan Program KKN Tematik lainnya yang relevan dan tambahan program inti, (c) Pengembangan dan pemantapan program inti dan program tambahan, (d) Monitoring dan evaluasi program KKN Tematik.

Tahap 4 Pendokumentasian Pengetahuan, meliputi: (a) Seminar Hasil kepada DPL, LPPM, Pemerintah Desa, dan Masyarakat, (b) Dokumentasi kegiatan dan (c) Laporan Kegiatan.

Tahapan kegiatan dimaksud berkenaan dengan pelaksanaan dilapangan setelah mahasiswa memulai program di desa lokasi KKN. Kegiatan persiapan dalam bentuk pembekalan mahasiswa peserta KKN Tematik dan fasilitasi kegiatan lainnya dilakukan langsung oleh LPPM Universitas Negeri Gorontalo. Untuk kegiatan di lokasi desa KKN Tematik, mahasiswa melaksanakan berbagai kegiatannya berdasarkan program kerja yang disusun bersama dengan masyarakat dari hasil observasi/ identifikasi kebutuhan yang mendesak sebagai program prioritas desa.

Penyelenggara kegiatan pembinaan keterampilan produktif adalah dosen sebagai dharma pengabdian masyarakat yang berasal dari Jurusan Pendidikan Luar Sekolah Fakultas IImu Pendidikan Universitas Negeri Gorontalo, dosen Jurusan Akuakultur Fakultas Sains dan Teknologi Universitas Muhammadiyah Gorontalo, para praktisi bidang keterampilan dibantu oleh mahasiswa dan difasilitasi sepenuhnya oleh masyarakat sasaran masing-masing keterampilan.

Data hasil kegiatan pengabdian masyarakat dilakukan dengan pendekatan dan analisis deskriptif kualitatif, dengan pertimbangan karena sebahagian data yang diperoleh bersumber dari observasi, wawancara dan dokumen yang terkait dengan fokus kegiatan pengabdian masyarakat. Adapun data yang dipaparkan secara kuantitatif untuk memberikan informasi guna mendukung data kualitatif sehingga diperoleh simpulan yang lebih konprehensif. 


\section{HASIL DAN PEMBAHASAN}

\section{Hasil}

Sebagaimana telah dikemukakan pada uraian sebelumnya bahwa urgensi pendidikan kecakapan hidup bagi setiap pribadi karena masyarakat menghadapi berbagai masalah yang harus senantiasa diselesaikan dalam kehidupannya sehari-hari. Kecakapan hidup itulah yang diperlukan pada individu memasuki kehidupan yang mandiri, anggota masyarakat dan warga negara. Sehingga dengan penguasaan terhadap life skills, individu diharapkan akan menjadi individu yang mampu memecahkan permasalahan-permasalahannya dengan menemukan alternatif atau solusi yang tepat yang berimplikasi positif bagi dirinya sendiri maupun bagi orang-orang yang berada di sekitar kehidupannya.

Pembinaan keterampilan produktif sebagai salah implementasi pendidikan kecakapan hidup perlu dikembangkan di kawasan masyarakat desa pesisir karena dengan bekal pengetahuan dan keterampilan yang dimiliki menjadi solusi terhadap permasalahan yang dihadapi dan pada gilirannya diharapkan dapat mampu meningkatkan kualitas hidup masyarakat desa sejalan dengan gerakan desa membangun.

Kegiatan pembinaan keterampilan produktif sebagai pengabdian masyarakat yang dilaksanakan terintegrasi dengan program dan kegiatan KKN Tematik Desa Membangun Tahun 2021 telah menyertakan beberapa unsur dalam pelaksanaannya. Unsur dimaksud antara lain, (1) dosen, (2) praktisi keterampilan, (3) mahasiswa, dan (4) masyarakat sasaran kegiatan.Ke empat unsur ini telah berperan sesuai fungsinya masingmasing berkolaborasi untuk suksesnya pembinaan keterampilan produktif sesuai target yang ditetapkan.

Secara umum terdapat 3 (tiga) faktor yang mempengaruhi bahkan mendukung pembinaan keterampilan produktif sebagai upaya pemberdayaan masyarakat desa pesisir. Ketiga faktor tersebut adalah terlaksananya pemberian keterampilan, termotivasinya masyarakat untuk belajar keterampilan sesuai potensinya, dan adanya informasi tentang fasilitas yang dapat dimanfaatkan untuk mengembangkan keterampilan. 
Dari pelaksanaan pembinaan keterampilan produktif bagi masyarakat desa Botuboluo Kecamatan Biluhu Kabupaten Gorontalo maka selanjutnya dideskripsikan data jenis kegiatan, kepesertaan dan capaian kegiatan sebagaimana tercantum dalam tabel 1 dan 2 berikut ini.

Tabel 1 Data Kegiatan dan Peserta Bina Keterampilan Produktif

\begin{tabular}{|c|c|c|c|c|}
\hline No. & Jenis Keterampilan & $\begin{array}{l}\text { Karateristik } \\
\text { Peserta }\end{array}$ & $\begin{array}{l}\text { Jumlah } \\
\text { Peserta }\end{array}$ & $\begin{array}{c}\text { Waktu } \\
\text { Pelaksanaan }\end{array}$ \\
\hline 1. & $\begin{array}{ll}\text { Bina/Pelatihan } & \text { Kelompok } \\
\text { Sadar Wisata } & \text { (Pokdarwis) } \\
\text { dan Kelompok Masyarakat } \\
\text { Pengawas (Pokmaswas) }\end{array}$ & $\begin{array}{c}\text { Pengelola, } \\
\text { Pokdarwis, } \\
\text { Pokmaswas dan } \\
\text { Pemuda }\end{array}$ & 28 & 4 Mei 2021 \\
\hline 2. & $\begin{array}{l}\text { Bina/Pelatihan } \\
\text { Badan Usaha } \\
\text { (BUMDES Miliki Delaan } \\
\text { (BUMas }\end{array}$ & $\begin{array}{c}\text { Pengelola } \\
\text { BUMDES, Karang } \\
\text { Taruna }\end{array}$ & 30 & 27 Mei 2021 \\
\hline 3. & $\begin{array}{l}\text { Bina/Pelatihan Pemanfaatan } \\
\text { Sampah Anorganik }\end{array}$ & $\begin{array}{l}\text { Karang Taruna dan } \\
\text { PKK }\end{array}$ & 25 & 28 Mei 2021 \\
\hline 4. & $\begin{array}{l}\text { Bina Keterampilan produk } \\
\text { olahan ikan Sulo-sulo (ikan } \\
\text { Sunglir) }\end{array}$ & $\begin{array}{l}\text { Pemuda dan } \\
\text { Nelayan }\end{array}$ & 35 & 25 Mei 2021 \\
\hline 5. & $\begin{array}{l}\text { Bina/ Keterampilan } \\
\text { Perawatan mesin katinting } \\
\text { bagi masyarakat nelayan }\end{array}$ & $\begin{array}{l}\text { Pemuda, Karang } \\
\text { Taruna nelayan }\end{array}$ & 25 & 10 Mei 2021 \\
\hline 6. & $\begin{array}{l}\text { Bina/Pelatihan humas IT } \\
\text { bagi organisasi kepemudaan }\end{array}$ & $\begin{array}{c}\text { Pemuda, Aparat } \\
\text { desa dan Pengurus } \\
\text { Organisasi } \\
\text { Pemuda }\end{array}$ & 27 & 29 Mei 2021 \\
\hline
\end{tabular}

Tabel 2 Data Kegiatan dan Capaian Program Bina Keterampilan Produktif

\begin{tabular}{|c|c|c|}
\hline No. & Kegiatan & Capaian Program \\
\hline 1. & $\begin{array}{l}\text { Bina/Pelatihan Kelompok } \\
\text { Sadar Wisata } \\
\text { (Pokdarwis) dan } \\
\text { Kelompok Masyarakat } \\
\text { Pengawas (Pokmaswas) }\end{array}$ & $\begin{array}{l}\text { a) Menjadikan masyarakat desa sebagai warga } \\
\text { yang sadar wisata dan peduli terhadap } \\
\text { kelestarian sumber daya alam untuk } \\
\text { dikembangkan sebagai sumber pendapatan } \\
\text { masyarakat } \\
\text { b) Meningkatnya pemahaman masyarakat terkait } \\
\text { pembinaan Pokmaswas dan Pokdarwis } \\
\text { c) Terbentuknya pola pikir masyarakat terkait } \\
\text { dampak dari pembinaan Pokmaswas dan } \\
\text { Pokdarwis. }\end{array}$ \\
\hline 2. & $\begin{array}{l}\text { Bina/Pelatihan } \\
\text { Pengelolaan Badan } \\
\text { Usaha Miliki Desa } \\
\text { (BUMDES) }\end{array}$ & $\begin{array}{l}\text { a) Meningkatnya pemahaman masyarakat } \\
\text { terhadap peningkatan sumberdaya alam yang } \\
\text { bernilai jual } \\
\text { b) Meningkatnya potensi masyarakat melalui } \\
\text { kegiatan keterampilan ekonomi produktif } \\
\text { c) Terbentuknya desa yang mandiri atas potensi } \\
\text { yang dimiliki } \\
\text { d) Meningkatnya partisipasi masyarakat terhadap } \\
\text { pentingnya pengelolaan anggaran desa yang } \\
\text { tepat sasaran dan tepat manfaatnya. }\end{array}$ \\
\hline 3. & $\begin{array}{l}\text { Bina/Pelatihan } \\
\text { Pemanfaatan Sampah } \\
\text { Anorganik }\end{array}$ & $\begin{array}{l}\text { a) Terciptanya keterampilan masyarakat desa } \\
\text { terhadap pemanfaatan sampah plastik dan } \\
\text { kaleng bekas }\end{array}$ \\
\hline
\end{tabular}


b) Teredukasinya masyarakat untuk menetralkan penggunaan sampah anorganik

c) Meningkatnya pengetahuan masyarakat dalam mengolah sampah anorganik menjadi suatu kreasi yang dapat didaur ulang dan bernilai ekonomis produktif.

a) Meningkatnya pengetahuan dan keterampilan masyarakat dalam mengolah ikan sulo-sulo

Bina Keterampilan

4. produk olahan ikan

Sunglir (Sulo-sulo).

Bina/ Keterampilan

5. Perawatan mesin

katinting bagi masyarakat nelayan (Sunglir) yang populasinya potensial dimiliki oleh Desa Botubuluo

b) Terbentuknya kesadaran masyarakat dalam membudidayakan ikan sulo-sulo (Sunglir) sebagai salah satu sumber pendapatan yang prospektif untuk dikembangkan.

a) Meningkatnya pengetahuan dan keterampilan nelayan maupun masyarakat desa mengenai tata cara perawatan rutin mesin katinting

b) Meningkatnya peran dan dukungan pemerintah desa untuk memfasilitasi warga masyarakatnya yang membuka jasa servis mesin katinting

a) Meningkatnya pengetahuan pemuda dan masyarakat desa dalam pemanfaatan penggunaan IT yang tepat sasaran dan tepat guna.

Bina/Pelatihan humas IT

6. bagi organisasi

kepemudaan

b) Meningkatnya kesadaran pemuda dan masyarakat dalam memanfaatkan IT untuk mendukung pengelolaan organisasi kepemudaan di desa.

Berdasarkan data tabel di atas, dapat dijelaskan bahwa pembinaan keterampilan produktif masyarakat yang berhasil dilaksanakan meliputi 6 jenis keterampilan yaitu: (1) Bina dan pelatihan kelompok sadar wisata, (2) pengelolaan BUMDES, (3) pemanfaatan sampah organik, (4) pelatihan produk olahan ikan sunglir (sulo-sulo). (5) keterampilan perawatan mesin katinting, dan (6) pelatihan humas IT bagi organisasi kepemudaan. Jenis keterampilan ini dipilih berdasarkan identifikasi dan analisis kebutuhan yang dilaksanakan di desa lokasi kegiatan. Kecuali itu pembinaan keterampilan diharapkan dapat mengatasi masalah yang dihadapi sekaligus menjadi alternatif pengembangan pengetahuan dan keterampilan yang sangat diperlukan. Kegiatan pembinaan ini telah melibatkan berbagai komponen masyarakat sebagai pesertanya yaitu ; para pemuda, pengurus karang taruna, aparat desa, Pengelola Kelompok Sadar Wisata (Pokdarwis), Kelompok Masyarakat Pengawas 
(Pokmaswas), Pengelola Badan Usaha Milik Desa (BUMDES), Pengurus PKK, dan masyarakat nelayan.

\section{Pembahasan}

Kegiatan pembinaan keterampilan produktif bagi masyarakat kawasan pesisir Desa Botuboluo telah menujukkan capaian target dari asfek penyelenggaraan dan keterlibatan masyarakat sasaran, antara lain: (1) menjadikan masyarakat desa sebagai warga yang sadar wisata dan peduli terhadap kelestarian sumber daya alam untuk dikembangkan sebagai sumber pendapatan masyarakat, (2) meningkatnya partisipasi masyarakat terhadap pentingnya pengelolaan anggaran desa yang tepat sasaran dan tepat manfaatnya, (3) meningkatnya pengetahuan masyarakat dalam mengolah sampah anorganik menjadi suatu kreasi yang dapat didaur ulang dan bernilai ekonomis produktif, (4) terbentuknya kesadaran masyarakat dalam membudidayakan ikan sulo-sulo (Sunglir) sebagai salah satu sumber pendapatan yang prospektif untuk dikembangkan, (5) meningkatnya pengetahuan dan keterampilan nelayan maupun masyarakat desa mengenai tata cara perawatan rutin mesin katinting, dan (6) meningkatnya kesadaran pemuda dan masyarakat dalam memanfaatkan IT untuk mendukung pengelolaan organisasi kepemudaan di desa.

Dari implementasi kegiatan pembinaan keterampilan produktif pada masyarakat desa kawasan pesisir menunjukkan bahwa pada prinsipnya pendekatan pola pendidikan kecakapan hidup yang menjadi bagian dari peningkatan pengetahuan, sikap dan keterampilan diharapkan menjadi salah satu alternatif solusi yang bijak dalam penanganan masyarakat pesisir guna mendapatkan kesempatan yang sama dalam menikmati pendidikan yang sesuai untuk mendukung upaya peningkatan pendapatan dan taraf hidup mereka.

Masyarakat kawasan pesisir memiliki karakteristik yang khas dibandingkan dengan kelompok masyarakat yang lain. Sebagaimana lazimnya, suatu komunitas memiliki nilai budaya tersendiri yang dipahami 
oleh masyarakatnya dalam membentuk tindakan sehari-hari. Faktor ekologi sangat berpengaruh terhadap tindakan yang dilakukan sehari-hari. Selain itu, faktor nilai budaya yang dimiliki oleh kelompok masyarakat pesisir ini akan berpengaruh pada pemahaman mereka terhadap pendidikan. Kondisi inilah yang akan menjadi dasar dalam membangun model pendidikan yang harus dilakukan.

Selanjutnya perhatian terhadap peningkatan taraf kehidupan masyarakat pesisir dan pulau-pulau kecil tidak pernah berhenti, misalnya diluncurkannya program pemberdayaan masyarakat pesisir pada tahun 2000. Perhatian itu didasari oleh pertimbangan bahwa wilayah pesisir mempunyai potensi kekayaan sumber alam yang sangat besar dan potensi sosial ekomoni yang harus diberdayakan. Kekayaan alam tidak hanya bersumber dari keanekaragaman sumber hayati laut, tetapi juga pantai yang menyuguhkan pemandangan nan eksotis yang layak untuk dijual. Sedangkan potensi sosial ekonomi yang dimiliki adalah masyarakat pesisir itu sendiri yang akan mengolah sumber daya alam yang telah tersedia.

Fenomena umum yang sering terdapat pada masyarakat kawasan pesisir antara lain kondisi sosial ekonomi kurang kondusif, dan tingkat pendidikan juga yang relatif rendah, sebagian karakteristik ini yang berpengaruh terhadap kualitas hidup mereka. Temuan penelitian Adharti dalam jurnal (Yulianti \& Goenadhi, 2016) menjelaskan bahwa penyebab kemiskinan nelayan secara umum adalah pendidikan dan keterampilan yang rendah. Akibatnya para nelayan tidak mempunyai pengetahuan dan keterampilan untuk mengolah hasil laut yang bermutu tinggi sehingga mempunyai nilai jual yang tinggi.

Dalam konteks kajian pendidikan luar sekolah sebagai pendidikan yang berbasis masyarakat memiliki keleluasaan dalam membina dan mengembangkan program-programnya yang sesuai dengan potensi dan kondisi sosial ekonomi masyarakat. Pendidikan Luar Sekolah memiliki peran yang urgen di tengah perkembangan ilmu pengetahuan dan teknologi yang berlangsung semakin cepat menimbulkan kebutuhan yang 
beraneka ragam dalam hal peralihan informasi, pengetahuan serta keterampilan guna pengembangan potensi perempuan kepala keluarga dengan menyeimbangkan antara pengetahuan dan keterampilan fungsional) (Isa et al., 2017). Sesuai dengan prinsip tersebut, maka pembinaan keterampilan produktif yang dikembangkan dalam kegiatan pengabdian masyarakat ini, menunjukkan bahwa Pendidikan Luar Sekolah memiliki keluasan dalam hal pengembangan program dan pengendalian konsep-konsep yang selalu menjadi acuan dalam penyelenggaraan pendidikan, pembinaan dengan sasaran targetnya masyakarat guna memenuhi kebutuhan untuk peningkatan pendapatan dan kualitas hidupnya.

Gambar 1 Luaran Media Berita Online

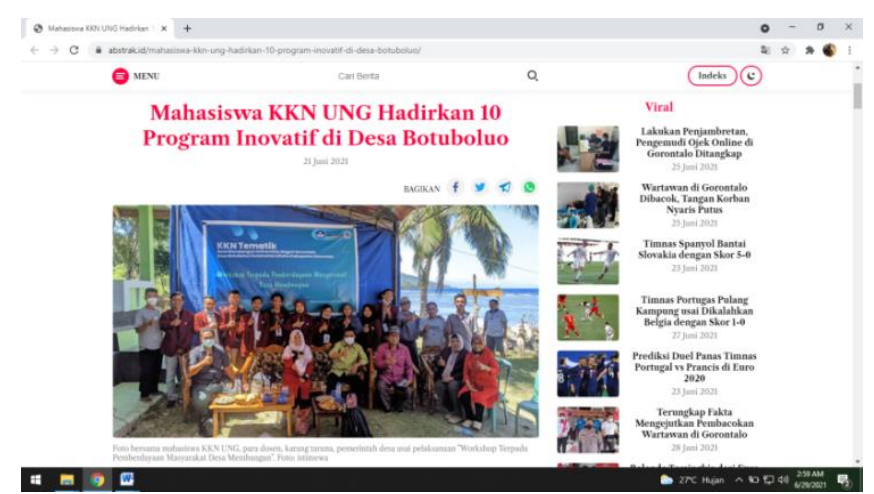

Sumber: https://abstrak.id/mahasiswa-kkn-ung-hadirkan-10-program-inovatif-di-desabotuboluo/

Gambar 2 Luaran Kegiatan melalui Chanel Youtube

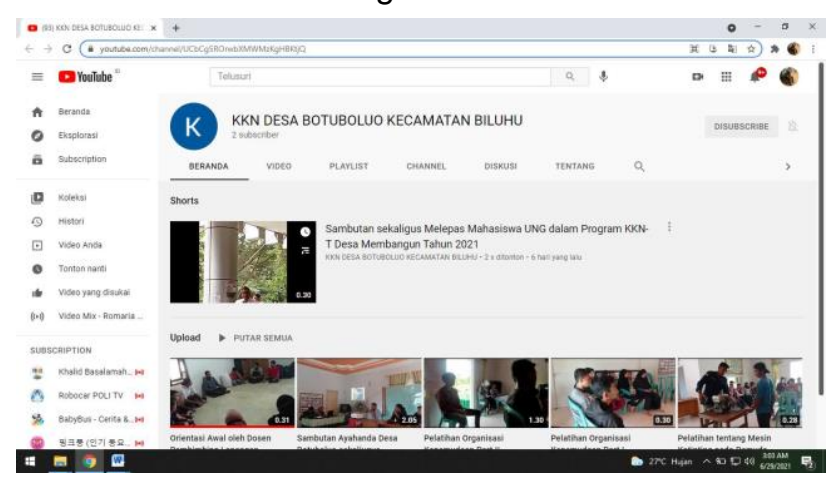

Sumber: https://www.youtube.com/channel/UCbCg5ROrwbXMWMzKgHBKtjQ

\section{KESIMPULAN}

Pembinaan keterampilan produktif bagi masyarakat kawasan pesisir desa Botuboluo telah berhasil dilaksanakan dan telah mampu melibatkan komponen masyarakat sasaran sebagai peserta kegiatan. Kegiatan ini 
sebagai salah satu wujud pengabdiaan masyarakat oleh Perguruan Tinggi. Dampak kegiatan ini makin optimalnya gerakan desa membangun yang diindikasikan dengan masyarakat desa terdorong menjadi mandiri dalam merumuskan langkahnya membangun kesejahteraan desa. Masyarakat lebih bersemangat menjalankan pembangunan desanya karena mereka memiliki hak dan wewenang untuk menentukan yang seharusnya mereka butuhkan. Direkomendasikan agar kegiatan pembinaan keterampilan produktif perlu dilanjutkan sebagai upaya memberdayakan masyarakat guna memantapkan peran mereka sebagai subyek dalam gerakan desa membangun.

\section{UCAPAN TERIMA KASIH}

Kegiatan pengabdian masyarakat terintegrasi dengan pelaksanaan Kuliah Kerja Nyata Tematik UNG Tahun 2021 yang berlokasi di Desa Botuboluo Kecamatan Biluhu Kabupaten Gorontalo terlaksana atas dukungan dan fasilitas dari berbagai pihak. Ucapan terima kasih kepada Rektor UNG dan Kepala LP2M UNG yang telah memberikan fasilitas pendanaan untuk pelaksanaan kegiatan pengabdian masyarakat ini.

Kepada Pemerintah desa Botuboluo melalui Kepada Desa dan jajarannya yang telah mengambil peran dalam penyelenggaraan kegaiatan pengabdian masyarakat. Ucapan terima kasih disampaikan pula kepada mahasiswa Peserta KKN Tematik UNG atas kerjasama dan partisipasinya dalam pelaksanaan kegiatan ini. Kepada masyarakat desa yang telah turut serta mendukung dan menyukseskan semua program ini diucapkan terima kasih yang sebesar-besarnya, semoga kegiatan pengabdian masyarakat yang dilaksanakan di desa ini memberi manfaat bagi optimalisasinya gerakan desa membangun yang dikembangkan di Desa Botuboluo.

\section{REFERENCES}

Ghufran, M., \& K., H. K. (2020). Mencapai Tujuan Pembangunan Berkelanjutan dari Desa. BaKTI News. https://baktinews.bakti.or.id/artikel/mencapai-tujuan-pembangunanberkelanjutan-dari-desa

Isa, A. H., Napu, Y., \& Zubaidi, M. (2017). Prosiding: Seminar dan 
Lokakarya PLS FIP UNG. In UNG Press.

Kurniawan, B. (2015). DESA MANDIRI, DESA MEMBANGUN. In Cetakan Pertama (p. 27).

LP2M, \& UNG. (2021). (Term of Reference) Kuliah Kerja Nyata (KKN) Tematik Desa https://repository.ung.ac.id/get/kms/22685/TOR-KKN-T-DesaMembangun-Th-2021.pdf

Tampubolon, D. (2003). STRATEGI PEMBERDAYAAN MASYARAKAT PESISIR DI KABUPATEN KEPULAUAN MERANTI Dahlan Tampubolon Laboratorium Ekonomi Pembangunan Regional Universitas Riau, Pekanbaru. Sorot, 8(2), 153-161.

Yulianti, F., \& Goenadhi, L. (2016). Analisis Pemberdayaan Masyarakat Pesisir Kabupaten Tanah Bumbu. Jurnal Spread, 6(2), 17-26. 